\title{
EFEKTIFITAS BAKTERI Pseudomonas SEBAGAI PENGURAI BAHAN ORGANIK (PROTEIN,KARBOHIDRAT,LEMAK) PADA MEDIA AIR LIMBAH PEMBENIHAN IKAN LELE DUMBO (Clarias SP.) SISTEM RESIRKULASI TERTUTUP
}

\section{EFFECTIVENESS OF Pseudomonas DECOMPOSING ORGANIC MATTER (PROTEIN, CARBOHYDRATE, LIPID) IN WASTE WATER OF DUMBO BREEDING FISH CATFISH (Clarias sp.) CLOSED SYSTEM RESIRCULATION}

\author{
Boedi S. Rahardja, Prayogo, Gunanti Mahasri dan Mochammad Dwi Hardhianto \\ Fakultas Perikanan dan Kelautan Universitas Airlangga \\ Kampus C Mulyorejo - Surabaya, 60115 Telp. 031-5911451
}

\begin{abstract}
Raising fish rearing African catfish lately more and more attention due to its economical value, easy to maintain and grow quickly. Quality of water at seeding activities have received attention because of seed is a phase that is still vulnerable to environmental changes so that the replacement of water and absolutely must be done if the accumulation of organic materials that cause toxic. African catfish fish hatcheries closed recirculation system based on the work system of water management repeatedly by using a filter (filter) and decomposing bacteria. This study aimed to determine whether the bacterium Pseudomonas pseudomallei index of $97.81 \%$ sp, Pseudomonas stutzeri index $61.21 \%$ and $97.81 \%$ of Pseudomonas stutzeri index may decompose the organic material in an aqueous medium Clarias gariepinus hatchery closed recirculation system and how long required to decompose proteins, lipid and carbohidrat. This research method using descriptive methods, aims to describe symptoms that are based on data collected by observation. Factors include the observation of incubation time at the beginning of the experiment, day 3, day 6 and day-to-9 after incubation performed. This study uses four treatments, namely A (water catfish hatcheries closed recirculation system with the addition of the bacteria Pseudomonas pseudomallei index of $97.81 \%$ ), B (catfish hatchery water recirculation system closed with the addition of the bacteria Pseudomonas stutzeri index of 97.81\%), C (catfish hatchery water recirculation system closed with the addition of the bacteria Pseudomonas stutzeri index of $61.21 \%$ and D (catfish hatchery water recirculation system closed with the addition of Pseudomonas pseudomallei index of 97.81\%, 97.81\% index of Pseudomonas stutzeri and Pseudomonas stutzeri index of 61.21\%). Result of this research shows that granting of Pseudomonas pseudomallei sp index $97.81 \%, 61.21 \%$ index of Pseudomonas stutzeri and Pseudomonas stutzeri index decreased $97.81 \%$ to give the effect of the proteins, lipid, carbohydrates, BOD and COD. The highest reduce protein content, lipid, carbohydrates, BOD and COD become to combination of pseudomonas bacteria after nine days.
\end{abstract}

Keywords : Pseudomonas, decomposing organic matter, protein, carbohydrate, lipid, BOD, COD

\section{Pendahuluan}

Pembenihan ikan lele dumbo selama ini dilakukan di daerah dengan potensi sumber air yang melimpah, karena benih merupakan fase yang masih rentan terhadap perubahan lingkungan sehingga kualitas air perlu diperhatikan. Penggantian air mutlak harus dilakukan apabila terjadi akumulasi bahan organik yang dapat menyebabkan toksik pada organisme yang dipelihara (Puspowardoyo dan Dariyah, 2002). Hal ini menyebabkan kendala bagi daerah yang kurang potensi sumber airnya. Permasalahan kurangnya potensi sumber air pada suatu daerah dapat menggunakan sistem untuk mengoptimalkan pemanfaatan air, yaitu dengan pembenihan sistem resirkulasi tertutup.
Pembenihan sistem resirkulasi tertutup kandungan bahan organik perairan akan meningkat sehingga dibutuhkan bakteri yang bisa mengurai kandungan bahan organik tersebut. Menurut Simajuntak (1996) pada pembenihan ikan lele (Clarias sp), kualitas air yang layak merupakan salah satu faktor penentu keberhasilan. Komponen bahan organik yang merupakan sumber bahan pencemar kualitas air umumnya adalah bahan organik yang terdiri dari protein, lemak dan karbohidrat (Droste, 1997), sehingga dalam penguraian bahan organik tersebut diperlukan adanya bakteri dari golongan bakteri proteoliktik, bakteri lipoliktik dan bakteri amiloliktik. Hasil eksplorasi penelitian Herlina (2010) diketahui bahwa bakteri yang bersifat proteolitik, amilolitik dan 
lipolitik yaitu Pseudomonas pseudomallei sp. indeks 97,81 \% adalah bakteri lipolitik, Pseudomonas stutzeri indeks $61,21 \%$ dan Pseudomonas stutzeri indeks 97,81\%, sehingga perlu dilakukan uji efektifitas pada media air pembenihan ikan lele dumbo (Clarias sp.) yang mengandung bahan organik.

Perumusan masalah pada penelitian ini adalah apakah bakteri Pseudomonas pseudomallei sp. indeks 97,81\%, Pseudomonas stutzeri indeks 61,21 \% dan Pseudomonas stutzeri indeks 97,81\% dapat mengurai bahan organik (protein, karbohidrat, lemak) dan berapa lama waktu yang dibutuhkan untuk mengurai bahan organik pada media air limbah pembenihan ikan lele dumbo sistem resirkulasi tertutup.

Tujuan penelitian ini adalah mengetahui apakah bakteri Psedumonas pseudomallei indeks $97,81 \%$, Pseudomonas stutzeri indeks $61,21 \%$ dan Pseudomonas stutzeri indeks $97,81 \%$ dapat mengurai bahan organik (protein, karbohidrat, lemak) dan berapa lama waktu yang dibutuhkan untuk mengurai bahan organik pada media air pembenihan ikan lele dumbo sistem resirkulasi tertutup

\section{Metodologi Penelitian \\ Tempat dan Waktu}

Penelitian ini dilaksanakan pada bulan Juni 2009 di Laboratorium Mikrobiologi Fakultas Sains dan Teknologi Universitas Airlangga. Pengujian kandungan protein, kandungan karbohidrat dan kandungan lemak di Balai Besar Laboratorium Kesehatan Surabaya.

\section{Materi Penelitian}

Materi penelitian yang digunakan terdiri atas alat dan bahan penelitian. Alat penelitian yang digunakan adalah seperangkat alat untuk kultur bakteri; tabung reaksi, petri disk, api bunsen, spatula, ose serta seperangkat alat untuk pembuatan media; erlenmeyer, becker glass, gelas ukur, autoclave,dan spektophotometer. Peralatan sterilisasi yaitu oven dan autoclave sedangkan peralatan untuk pengenceran dan pengukuran menggunakan timbangan analitik digital Sartorius dan mikroskop cahaya (spektrofotometer). Bahan penelitian yang digunakan adalah bakteri pengurai bahan organik Pseudomonas pseudomallei sp. indeks 97,81\%, Pseudomonas stutzeri indeks $61,21 \%$ dan Pseudomonas stutzeri indeks $97,81 \%$ dan aquades yang sudah di autoclave atau disterilisasikan. Media air yang digunakan berasal dari pembenihan ikan lele sistem resirkulasi tertutup yang berasal dari
Desa Plosowahyu, Kecamatan Lamongan, Kabupaten Lamongan.

\section{Metode Penelitian}

Penelitian ini menggunakan metode deskriptif. Faktor waktu inkubasi meliputi pengamatan pada awal percobaan, hari ke-3, hari ke-6 dan hari ke-9 setelah inkubasi dilakukan. Penelitian ini menggunakan pemberian dosis bakteri sebanyak $75 \mathrm{ml}$ dengan OD (Optical Density) 5 dan kepadatan bakteri $6 \mathrm{x} 10^{10} \mathrm{CFU} / \mathrm{ml}$. Penelitian ini dibagi menjadi 4 kelompok yaitu A (Air pembenihan lele sistem resirkulasi tertutup dengan penambahan bakteri Pseudomonas pseudomallei indeks 97,81\%), B (Air pembenihan lele sistem resirkulasi tertutup dengan penambahan bakteri Pseudomonas stutzeri indeks 97,81\%), C (Air pembenihan lele sistem resirkulasi tertutup dengan penambahan bakteri Pseudomonas stutzeri indeks 61,21\%), D (Air pembenihan lele sistem resirkulasi tertutup dengan penambahan bakteri Pseudomonas pseudomallei 97,81\%, Pseudomonas stutzeri 97,81 \% dan Pseudomonas stutzeri indeks 61,21\%)

\section{Prosedur Penelitian}

A. Persiapan peralatan

Peralatan yang digunakan dalam penelitian ini harus disterilisasi dengan tujuan untuk menghindari kontaminasi. Langkah awal yang dilakukan dengan mencuci peralatan menggunakan deterjen kemudian dibilas dengan air. Peralatan tersebut dikeringkan dan ditutup dengan aluminium foil untuk menjaga agar terhindar dari kontaminasi pengaruh dari luar dan dimasukkan ke autoclave. Autoclave diatur dengan suhu $121^{\circ} \mathrm{C}$ selama 15 menit agar tercipta suasana yang steril.

\section{B. Persiapan Air Media}

Air media diambil dari pembenihan system resirkulasi tertutup di desa plosowahyu, Kecamatan Lamongan Kabupaten Lamongan. Media air diambil setelah masa panen sehingga dikondisikan kandungan BOD dan COD yang tinggi untuk mengetahui efektifitas bakteri pengurai. Air yang sudah diambil disterilisasi dengan autoclave. Sterilisasi dilakukan dengan air sebanyak 20 liter menggunakan autoclave dalam suhu $121^{\circ} \mathrm{C}$ selama 15 menit tekanan 15 atm agar tercipta suasana yang steril.

C. Pembuatan / penyiapan bakteri

a. Pembuatan media pertumbuhan bakteri berupa 
Media Nutrien Agar (NA) dibuat dengan cara menimbang 0,02 gr media dan dilarutkan dalam aquades pada becker glass. Media NA dipanaskan hingga larut kemudian media dalam becker glass diangkat dan ditunggu hingga uap panasnya hilang. Media tersebut dibagi kedalam tabung reaksi. Tiap tabung reaksi berisi $5 \mathrm{ml}$ media NA yang kemudian ditutup menggunakan kapas dan terakhir dilapisi dengan alumunium foil. Sisa dari media dimasukkan kedalam erlenmayer dan ditutup dengan kapas dan alumunium foil. Media NA disterilkan dengan menggunakan autoclave dengan suhu $121^{\circ} \mathrm{C}$ dengan tekanan 1 atm. Setelah disterilkan dengan menggunakan autoclaf, media dalam tabung reaksi dimiringkan hingga diperoleh media miring (Hadietomo, 1993). Media dalam erlenmeyer dibagi dalam cawan petri sebanyak $15 \mathrm{ml}$ media. Media didiamkan hingga menjadi padat.

\section{b. Persiapan bakteri Pseudomonas pseudomallei dan Pseudomonas stutzeri Pseudomonas pseudomallei} diremajakan dengan cara mengambil bakteri menggunakan ose kemudian dipindahkan ke media NA yang baru. Bakteri diinkubasi pada suhu ruang $29-30^{\circ} \mathrm{C}$ dengan lama waktu \pm 24 jam (Hadioetomo, 1993). Bakteri Pseudomonas pseudomallei dan Pseudomonas stutzeri diambil dengan menggunakan ose lalu dimasukkan ke dalam tabung erlenmeyer berisi aquadest $75 \mathrm{ml}$ yang telah disterilisasi. Proses sterilisasi menggunakan autoclave dengan suhu $121^{\circ} \mathrm{C}$ selama 15 menit. Larutan yang berisi aquadest dan bakteri kemudian dihomogensikan menggunakan vortex. Isolat tersebut kemudian diukur nilai OD (Optical density) menggunakan spektrofotometer. Masukkan sample larutan ke dalam cuvet yang telah disediakan. Cuvet kemudian dimasukkan ke dalam spektrofotometer untuk mengetahui nilai OD dari larutan tersebut. Bakteri yang telah siap diaplikasikan ke dalam media.

\section{c. Inokulasi bakteri pengurai}

Bakteri Pseudomonas pseudomallei dan Pseudomonas stutzeri yang telah ditentukan nilai OD nya kemudian diinokulasikan ke media air dari pembenihan resirkulasi tertutup.

\section{Parameter Pengamatan}

Parameter Utama

\section{A. Pemeriksaan Kadar Amilum}

Pemeriksaan kadar amilum dilakukan dengan terlebih dahulu menyaring media air yang digunakan dan ampas yang dihasilkan ditimbang sebanyak 5 gram kemudian tambahkan aquadest $50 \mathrm{ml}$. Larutan diaduk selama 1 jam kemudian disaring filtrate larutan tersebut. Ampas yang dihasilkan dilarutkan dengan aquadest dalam labu lod. Selanjutnya $20 \mathrm{ml}$ $\mathrm{HCl}$ pekat ditambahkan kemudian larutan tersebut dipanaskan di atas waterbath yang mendidih selam 2,5 jam. Setelah itu larutan didinginkan dan dinetralkan pada labu ukur sampai $250 \mathrm{ml}$. Di dalam labu lod, $25 \mathrm{ml}$ sample ditambahkan $25 \mathrm{ml}$ lod $0,1 \mathrm{~N}$ dan 5 $\mathrm{ml} \mathrm{NaOH} 0,5 \mathrm{~N}$ kemudian didiamkan di tempat gelap dan ditambahkan $5 \mathrm{ml} \mathrm{HCl} 2$ N. Selanjutnya dilakukan proses titrasi dengan $\mathrm{Na}$ thiosulfat $0,1 \mathrm{~N}$ dan aquadest digunakan sebagai blanko (Departemen Kesehatan RI, 1993)

\section{B. Pemeriksaan Kadar Protein}

Pemeriksaan kadar protein dilakukan dengan penimbangan bahan \pm 3 gram lalu dimasukkan ke dalam labu kjehldal. Kemudian dilakukan proses destruksi dengan ditambahkan asam kuat dan dipanaskan sampai jernih, kemudian dinginkan dan dimasukkan ke dalam labu ukur $250 \mathrm{ml}$. Selanjutnya dilakukan pengambilan larutan sebanyak $2 \mathrm{ml}$ lalu dimasukkan ke dalam tabung nessler dan ditambahkan aquadest. Larutan selanjutnya dinetralkan dengan $\mathrm{NaOH} 40 \%$, dilakukan pengecekan $\mathrm{pH}$ larutan dengan kertas $\mathrm{pH}$ kemudian ditambahkan aquadest hingga volume menjadi $50 \mathrm{ml}$. Selanjtnya dilakukan kembali pengambilan larutan dengan pipet sebanyak $2 \mathrm{ml}$ kemudian dimasukkan ke dalam tabung nessler lalu ditambahkan aquadest hingga volume menjadi $25 \mathrm{ml}$. Kemudian ditambahkan garam Rochelle dan reagen nessler $1,5 \mathrm{ml}$ dan kocok perlahan hingga homogen. Ukur absorban dengan spektrofotometer pada $\lambda=$ 425 nm (Departemen Kesehatan RI, 1993).

\section{Pemeriksaan Kadar Lemak}

Pemeriksaan lemak dilakukan dengan 2-5 gram bahan contoh, masukkan contoh bahan ke dalam kertas saring selanjutnya dimasukkan dalam tabung reaksi Soxhlet dalam thimble dan dialirkan air pendingin dari kondensor. Pasang tabung ekstraksi pada alat destilasi Soxhlet dengan pelarut Petroleum Ether selama 4 jam, selanjutnya Petroleum Ether yang telah mengandung ekstrak lemak dan minyak dipindahkan ke dalam botol timbang / labu iod yang telah diketahui beratnya kemudian diuapkan dengan pemanas air. Setelah mengalami 
proses penguapan maka dilanjutkan dengan pengeringan dalam oven dengan suhu $100^{\circ} \mathrm{C}$ sampai mencapai berat yang konstan. Berat residu dalam botol timbang dinyatakan sebagai berat lemak dan minyak (Departemen Kesehatan RI, 1993)

\section{Parameter Pendukung}

Parameter pendukung yang diamati dalam penelitian ini adalah pengukuran BOD dan COD. Pengukuran BOD dan COD dilakukan pada hari ke-0, hari ke-3, hari ke-6 dan hari ke-9.

\section{Hasil dan Pembahasan}

A. Hasil Penentuan Kadar Protein Berdasarkan penelitian yang telah dilakukan, didapatkan hasil penelitian kadar protein pada setiap inokulan bakteri, yang ditampilkan pada Tabel 1.

Tabel 1. Hasil Penentuan Kadar Protein (mg/l)

\begin{tabular}{|c|c|c|c|c|}
\hline \multirow{2}{*}{ Perlakuan } & \multicolumn{4}{|c|}{ Waktu (hari) } \\
\cline { 2 - 5 } & 0 & 3 & 6 & 9 \\
\hline A & 78 & 58 & 51 & 34 \\
B & 78 & 54 & 40 & 20 \\
C & 78 & 62 & 58 & 39 \\
D & 78 & 59 & 49 & 18 \\
\hline
\end{tabular}

Berdasarkan tabel 1 dapat diketahui bahwa rata-rata kadar protein pada waktu awal penelitian (0 hari) mempunyai nilai paling tinggi pada setiap perlakuan bakteri, yaitu sebesar 78 mg/l. Pada hari ke 9, rata-rata kadar protein paling tinggi adalah pada perlakuan $\mathrm{C}$ sebesar $39 \mathrm{mg} / \mathrm{l}$, dan paling kecil pada perlakuan D sebesar $18 \mathrm{mg} / \mathrm{l}$.

A. Hasil Penentuan Kadar Karbohidrat

Hasil Penentuan kadar Karbohidrat pada setiap inokulan bakteri, disajikan pada Tabel 2.

Tabel 2. Hasil Penentuan Kadar Karbohidrat $(\mathrm{mg} / \mathrm{l})$

\begin{tabular}{|c|c|c|c|c|}
\hline \multirow{2}{*}{ Perlakuan } & \multicolumn{4}{|c|}{ Waktu (hari) } \\
\cline { 2 - 5 } & 0 & 3 & 6 & 9 \\
\hline A & 24 & 20 & 11 & 5 \\
B & 24 & 18 & 9 & 3 \\
C & 24 & 19 & 10 & 4 \\
D & 24 & 13 & 4 & 2 \\
\hline
\end{tabular}

Melalui tabel 2 dapat diketahui bahwa rata-rata karbohidrat pada waktu awal penelitian (0 hari) mempunyai nilai paling tinggi pada setiap perlakuan bakteri, yaitu sebesar $24 \mathrm{mg} / \mathrm{l}$. Kadar rata-rata karbohidrat menurun pada penambahan waktu. Pada hari ke 9, rata-rata karbohidrat paling tinggi adalah pada perlakuan A sebesar $5 \mathrm{mg} / \mathrm{l}$, dan paling kecil pada perlakuan D sebesar $2 \mathrm{mg} / \mathrm{l}$.

B. Hasil Penentuan Kadar Lemak

Data rata-rata kadar lemak pada setiap inokulan bakteri, disajikan pada Tabel 3

Tabel 3. Hasil Penentuan Kadar Lemak (mg/l)

\begin{tabular}{|c|c|c|c|c|}
\hline \multirow{2}{*}{ Perlakuan } & \multicolumn{4}{|c|}{ Waktu (hari) } \\
\cline { 2 - 5 } & 0 & 3 & 6 & 9 \\
\hline A & 32 & 28 & 19 & 11 \\
B & 32 & 26 & 13 & 4 \\
C & 32 & 29 & 21 & 12 \\
D & 32 & 24 & 16 & 6 \\
\hline
\end{tabular}

Tabel 3 menunjukkan bahwa rata-rata kadar lemak pada waktu awal penelitian (0 hari) mempunyai nilai paling tinggi pada setiap perlakuan bakteri, yaitu sebesar $32 \mathrm{mg} / \mathrm{l}$. Kadar rata-rata kadar lemak menurun pada penambahan waktu. Pada hari ke 9, rata-rata kadar lemak paling tinggi adalah pada perlakuan C sebesar $12 \mathrm{mg} / \mathrm{l}$, dan paling kecil pada perlakuan B sebesar $4 \mathrm{mg} / \mathrm{l}$.

\section{Hasil Penentuan Kadar BOD (Biological Oxygen Demand) \\ Hasil penentuan kadar BOD pada setiap} inokulan bakteri, disajikan pada Tabel 4.

Tabel 4. Hasil Penentuan Kadar BOD (mg/l)

\begin{tabular}{|c|c|c|c|c|}
\hline \multirow{2}{*}{ Perlakuan } & \multicolumn{4}{|c|}{ Waktu (hari) } \\
\cline { 2 - 5 } & 0 & 3 & 6 & 9 \\
\hline A & 410 & 287 & 158 & 45 \\
B & 410 & 311 & 177 & 53 \\
C & 410 & 353 & 197 & 92 \\
D & 410 & 307 & 111 & 35 \\
\hline
\end{tabular}

Tabel 4 menunjukkan bahwa rata-rata kadar BOD pada waktu awal penelitian (0 hari) mempunyai nilai paling tinggi pada setiap perlakuan bakteri yaitu sebesar $410 \mathrm{mg} / \mathrm{l}$. Kadar rata-rata kadar BOD menurun pada penambahan waktu. Pada hari ke 9, rata-rata kadar BOD paling tinggi adalah pada perlakuan $\mathrm{C}$ sebesar 92, dan paling kecil pada perlakuan D sebesar $35 \mathrm{mg} / \mathrm{l}$. Penurunan kadar BOD menjukkan penurunan yang cukup baik yaitu 91,4\%. Untuk pembenihan ikan lele dumbo (clarias sp.) kadar BOD 35 ppm belum bisa langsung diaplikasikan karena menurut Zahidah (2004) Standart 
parameter BOD pada perairan budidaya perikanan yaitu $3 \mathrm{ppm}$.

\section{Hasil Penentuan Kadar COD (Chemical Oxygen Demand) \\ Hasil Penentuan kadar COD pada setiap inokulan bakteri, disajikan pada Tabel 5.}

Tabel 5. Hasil Penentuan Kadar COD (mg/l)

\begin{tabular}{|c|c|c|c|c|}
\hline \multirow{2}{*}{ Perlakuan } & \multicolumn{4}{|c|}{ Waktu (hari) } \\
\cline { 2 - 5 } & 0 & 3 & 6 & 9 \\
\hline A & 354 & 349 & 233 & 135 \\
B & 354 & 338 & 275 & 167 \\
C & 354 & 339 & 280 & 150 \\
D & 354 & 334 & 229 & 110 \\
\hline
\end{tabular}

Tabel 5 menunjukkan bahwa rata-rata kadar COD pada waktu awal penelitian (0 hari) mempunyai nilai paling tinggi pada setiap perlakuan bakteri, yaitu sebesar $354 \mathrm{mg} / \mathrm{l}$. Kadar rata-rata kadar COD menurun pada penambahan waktu. Pada hari ke 9, rata-rata kadar COD paling tinggi adalah pada perlakuan B sebesar $167 \mathrm{mg} / \mathrm{l}$, dan paling kecil pada perlakuan D sebesar $110 \mathrm{mg} / \mathrm{l}$. . Penurunan kadar COD menjukkan penurunan yang cukup baik yaitu 69\%. Untuk pembenihan ikan lele dumbo (clarias sp.) kadar COD 110 ppm belum bisa langsung diaplikasikan karena menurut Wardoyo (1978) COD pada budidaya perairan kurang dari 25 ppm.

\section{Hasil dan Pembahasan}

Penambahan bakteri dari jenis pseudomonas pada media air pembenihan ikan lele dumbo mengakibatkan penurunan kandungan protein, amilum, lemak, BOD dan COD. Bakteri pseudomonas yang digunakan adalah bakteri Pseudomonas pseudomallei 97,81\%, bakteri Pseudomonas stutzeri 97,81\% dan bakteri Pseudomonas stutzeri 61,21\%.

Air media pembenihan ikan lele dumbo yang digunakan berasal dari air limbah pembenihan ikan lele dumbo system resirkulasi tertutup sehingga mempunyai kandungan bahan organik yang tinggi. Pada pengujian hari ke 3, 6 dan 9 terjadi penurunan yang signifikan terhadap kandungan protein, amilum, lemak, BOD dan COD. Protein, amilum dan lemak mengalami penurunan karena bakteri pseudomonas yang ditambahkan dapat melakukan proses penguraian protein, amilum dan lemak.

Proses penguraian protein yaitu proses enzim-enzim protease menghidrolisis protein menjadi senyawa polipeptida, oligopeptida dan asam-asam amino. Enzim protease, enzim ekstraseluler yang dikeluarkan oleh mikroba, berfungsi menghidrolisis ikatan peptida pada protein yang menghasilkan peptida lebih sederhana / asam amino.

Mekanisme penguraian dapat dilihat di bawah ini :

Protein $\stackrel{\text { Protease }}{\longrightarrow}$ peptida $\stackrel{\text { peptidase }}{\longrightarrow}$ asam amino

Bakteri yang mendegradasi amilum yaitu bakteri amilolitik yang dapat menghasilkan enzim amilase. Amilum dapat dipecah oleh berbagai mikroba amilolitik menjadi polimer yang lebih sederhana atau gula monosakarida, dimana monosakarida selanjutnya akan dipecah lagi menjadi energi. Mekanisme penguraian amilum dapat dilihat di bawah ini :

Amilum $\stackrel{\text { Amilase }}{\longrightarrow} \mathrm{CO}_{2}+\mathrm{O}_{2}+$ energi

Kandungan lemak pada media air pembenihan ikan lele dumbo mengalami penurunan dikarenakan pendegradasian lemak oleh bakteri lipolitik. Bakteri lipolitik merupakan bakteri penghasil lipase. Lipase merupakan enzim yang mampu mengkatalis reaksi hidrolisis triasilgliserol menjadi asam lemak dan gliserol (Gupta et al, 2003). Enzim lipase berfungsi mengkatalis trigliserida menjadi digliserida dan asam lemak.

Proses penguraian lipase adalah sebagai berikut :

Trigliserol $+\mathrm{H}_{2} \mathrm{O} \stackrel{\text { lipase }}{\longrightarrow}$ gliserol + asam lemak

Pengamatan BOD dan COD merupakan tolak ukur ada tidaknya aktivitas bakteri yang mengurai bahan organik. BOD dan COD merupakan parameter kebutuhan oksigen yang dibutuhkan mikroba untuk mendegradasi bahan organik. Menurut Zahidah (2004) nilai COD pada perairan budidaya yaitu 20 ppm.. Aktivitas mikroba untuk mengurai bahan organik membutuhkan oksigen yang cukup tinggi sehingga akan menaikkan kadar BOD dan COD. Menurut (Saefuddin, 2007) adanya bahan organik tinggi dalam air menyebabkan kebutuhan mikroba akan oksigen meningkat, yang diukur dari nilai BOD dan COD yang meningkat.

\section{Kesimpulan}

Pemberian bakteri Pseudomonas pseudomallei indeks 97,81\%, Pseudomonas stutzeri indeks $61,21 \%$ dan Pseudomonas stutzeri indeks $97,81 \%$ memberikan pengaruh 
penurunan kandungan protein, lemak, karbohidrat dan penurunan tertinggi kandungan bahan organik (protein, karbohidrat, lemak) terjadi pada penggunaan kombinasi bakteri bakteri Pseudomonas pseudomallei indeks 97,81\%, Pseudomonas stutzeri indeks $61,21 \%$ dan Pseudomonas stutzeri indeks $97,81 \%$ selama 9 hari.

Bakteri dari genus pseudomonas dapat digunakan sebagai bakteri pengurai bahan organik pada pembenihan ikan lele dumbo system resirkulasi tertutup sehingga dapat menurunkan kandungan protein, karbohidrat, lemak, BOD dan COD. Sebelum aplikasi bakteri pseudomonas pada pembenihan ikan lele dumbo sistem resirkulasi tertutup perlu penelitian untuk menentukan jumlah bakteri yang digunakan.

\section{Daftar Pustaka}

Departemen Kesehatan Republik Indonesia. 1993. Petunjuk Pemeriksaan Kualitas Air. Departemen Kesehatan Republik Indonesia. Jakarta.

Effendi, H. 2003. Telaah Kualitas Air : bagi pengelola sumberdaya dan lingkungan perairan. Kanisius. Yogyakarta. 258 hal.

Gupta, R., P. Rathi, N. Gupta dan S. Bradoo. 2003. Lipase Assays for conventional and Moleculas Screening : A Overview. Biotechol. Appl. Biochem. (37) 63 - 71.
Hadieotomo, Ratna Siri. 1993. Mikrobiologi Dasar Dalam Praktek. PT Gramedia Pustaka Utama. Jakarta

Herlina M.S. 2010. Isolasi Bakteri Indigen Sebagai Pendegradasi Bahan Organik Pada Pembenihan Ikan Lele Dumbo Sistem Resirkulasi Tertutup. Skripsi Fakultas Perikanan Dan Kelautan. Universitas Airlangga.

Pranoto. 2005. Penggunaan Biofilter Enceng Gondok (Eichhornia crassipes (mart)solm) untuk Menurunkan Kadar COD Limbah Cair dari Pabrik Tahu. Skripsi. Semarang: UNNES

Prihartono, K, Rasidik, J dan Arie, U. 2000. Mengatasi Permasalahan Budidaya Lele Dumbo. Penebar Swadaya. Jakarta.

Puspowardoyo, H dan Djarijah, A.S. 2002. Pembenihan dan Pembesaran Lele Dumbo Hemat Air. Kanisius. Yogyakarta.

Saefuddin. A. 2007. Bioremediasi. Institut Teknologi Bandung. Jawa Barat.

Simanjutak, R.H. 1996. Pembudidayaan Ikan Lele Lokal dan Dumbo. Bhratara. Jakarta.

Wardoyo, S.T.H. 1978. Kriteria Kualitas Air Untuk Keperluan Pertanian dan Perikanan hal 293-300.

Zahidah, 2004. Evaluasi Kelayakan Kualitas Air Untuk Budidaya Ikan Dalam Keramba Jaring Apung Di Waduk Cirata 